\title{
Sounding the Authentic Self:
}

\section{Artistic Expressions of a Queer Music Therapist}

\author{
Colin Andrew Lee ${ }^{1 *}$ \\ 1 Wilfrid Laurier University, Waterloo \\ *clee@wlu.ca
}

Received: 21 March 2019 Accepted: 7 October 2019 Published: 1 November 2019

Editors: Candice Bain, Maevon Gumble Reviewer: Brian Abrams

\begin{abstract}
This piece is a queer autoethnographic cycle of words, poems, and improvisations that reflect my lived experience as a queer music therapist. The improvisations come from a two-day recording session held at the Maureen Forrester Hall, Wilfrid Laurier University, Canada. By expressing my identity as a queer music therapist, I came to understand with greater clarity the therapeutic-creative process that was central to my work with clients. The music offered as part of my contribution to this queering music therapy special issue acknowledges the courage and peace needed to embrace my intersecting identities as a composer-music-therapist and a queer cisgender man.
\end{abstract}

Keywords: Queer autoethnography, musical expression, improvisation, queer identity, HIV/AIDS

\section{Prelude}

It was the summer of 1984. I had just completed my education at the Nordoff-Robbins music therapy centre Kentish Town, London. Watching television at home, I found myself transfixed by breaking news from San Francisco. A disease had been discovered called AIDS. In 1980, the first patient in the US had died from the illness. In the years since, the number of infected was growing, and it was now expected to become an epidemic. The disease affected primarily gay cisgender men through unprotected sex. Symptoms were harrowing and patients were dying within 2 to 3 years of their diagnosis. The report went on to describe how AIDS was already being called a 'gay plague.' Living in my sheltered suburban environment, this news was shocking. I had never heard of AIDS and knew nothing of a 'gay plague.' For me, San Francisco was a place where gay cisgender men could live and love with freedom. As I watched the news with testimonies from doctors and sick young men, I began to feel overwhelmed with feelings of fear and helplessness. I was gay and a music therapist. In my mind, at that time, these aspects of my life were separate. I had never considered working and acknowledging my identity as a gay cisgender man in my work and how it might affect my future practice. Yet, at that moment, I knew my life would change, and my professional and personal identities would merge. My destiny would be to work with gay cisgender men who were living with HIV/AIDS. For me, there was no choice. 


\section{Background}

The emergence of queer music therapy (Boggan, Grzanka, \& Bain, 2018; Bain, Grzanka, \& Crowe 2016) has created a critical expansion of music therapy theory and practice. As a self-identified queer music therapist (Lee 2016a, 2016b, 2019), I have advocated throughout my career that my proclaimed sexual identity has always been central to my clinical work. Working from 1988 to 1992 at London Lighthouse, a centre for people facing the challenge of AIDS, the clients I worked with were primarily gay cisgender men. My clinical practice was initially rooted in the Nordoff-Robbins tradition and later through my music-centered theory of Aesthetic Music Therapy (Lee 2003, 2016). As a composer and music therapist, I used improvisation as my main musical tool. At the beginning of my work, I knew of no other music therapists using improvisation in palliative care, and in particular, care for people living with HIV/AIDS. Because of this, I needed to re-evaluate the boundaries of my work and how best I could use improvisation to meet the needs of clients who were living with a palliative diagnosis. My practice in end of life care with clients living with HIV/AIDS changed not only my perceptions of my sexual identity and how it affected the therapeutic relationships in my work, but also the compositional structures of improvisation and the inherent dynamism of music. After my work at London Lighthouse, and completing my $\mathrm{PhD}$, I continued working in palliative care at Sir Michael Sobell House, Oxford from 1992 to 1996.

Queer autoethnography (Holman Jones \& Harris, 2019) is a contemporary qualitative research method intertwining both autoethnography and queer theory that has been recently introduced to music therapy (Gumble, 2019). Adams and Holman Jones $(2008,2011)$ discussed how autoethnography is in many ways queer and how it can more explicitly be queer when queer theory is used to ground the telling of stories. Queer autoethnography involves telling stories that deconstruct binary, fixed understandings; contextualize knowledge; and examine power and privilege. Additionally, queer autoethnography emphasizes using creative processes such as writing, music, art, and so on as a process of discovery, where we continue to 'become' as we engage in those processes (Adams \& Holman Jones, 2011). Prior to arriving at queer autoethnography, I recorded the improvisations that I have included in this paper and reflected deeply on specific clients and also general feelings and responses to my work. These recordings became the springboard for moving into queer autoethnography and this current article. It became clear to me that I would be able to uniquely express my musical self, utilizing the emphasis on narration and story-telling within this qualitative method. In my engagement with queer autoethnography, I am focusing on my personal experiences as a queer music therapist, recognizing that queer narratives might challenge our understanding of norms such as heteronormativity, cisnormativity, whiteness, and non-disabled-ness. The narrative experiences of queer music therapists could be crucial in challenging a mostly white, heterosexual, and female dominated profession. In this sense of queer autoethnography, it might provide a rich and vital opportunity to represent the self-expressions and explorations of queer music therapists, along with a potential to promote the much-needed diversity in contemporary music therapy as a culturally sensitive field.

In revealing my experiences as a queer music therapist, I understand that I face the risk of making my professional perspective different and even separate from that of my heterosexual colleagues. It is not my intention to isolate myself, but rather share my perceptions of the therapeutic process, and how I understand illness and disability as a queer music therapist. Indeed, I have often felt professionally alone-alone as a composer who has advocated for the centrality of music in therapy and alone as a self-identified queer cisgender man. These divergencies, though at times hard, I believe have made me stronger and helped me understand, with greater transparency, the complexities of the therapeutic relationship. In expressing my emotional-musical humanity, it is my hope that other music therapists will feel able to share their own therapeutic 


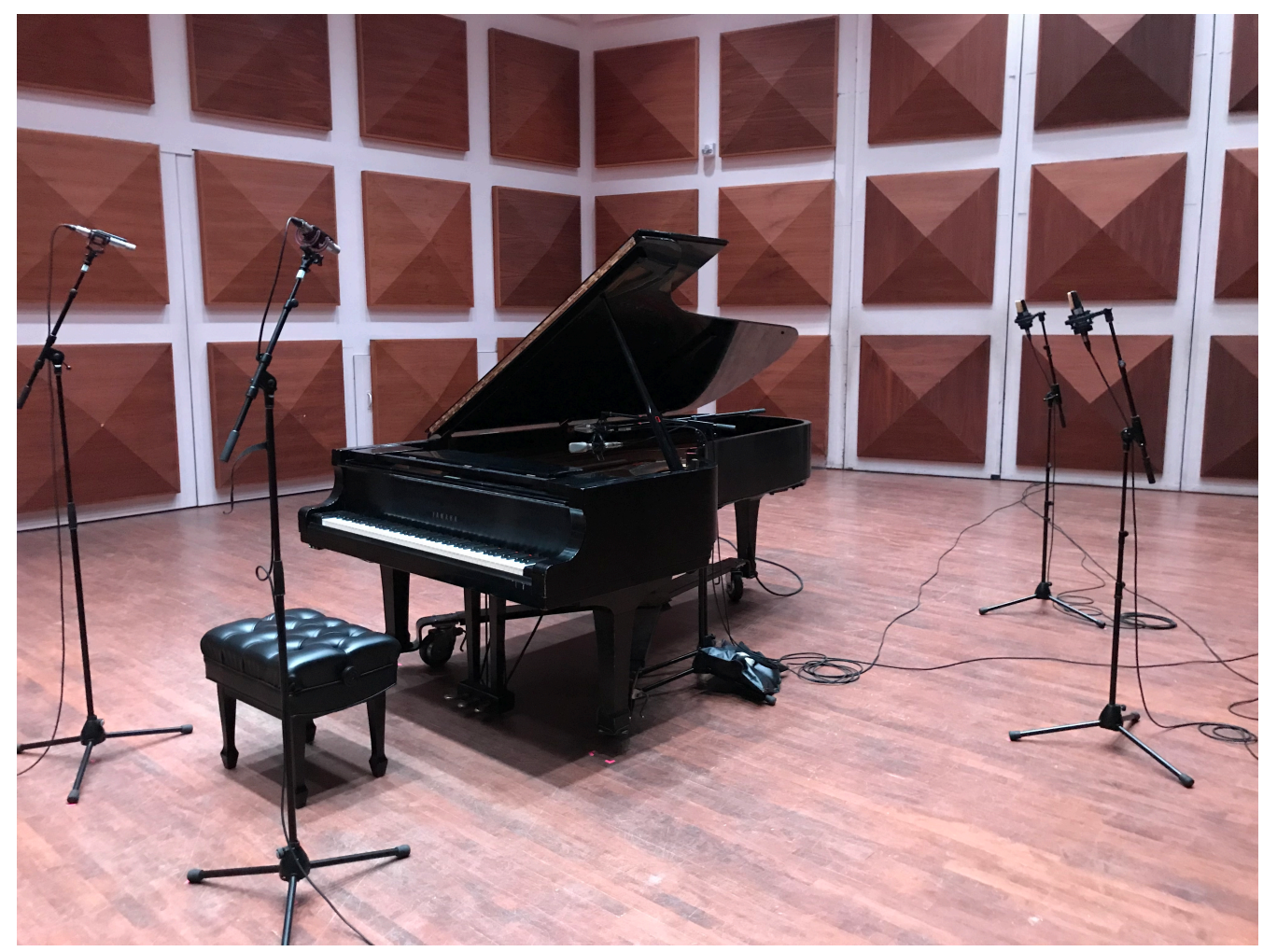

Figure 1

Pictured is the setting of the recording session in Maureen Forrester Hall, where there a grand piano with a bench is visible surrounded by four studio microphones.

and personal truths. Being a queer music therapist is a gift that I have embraced and always sought to professionally proclaim.

I am a musician, a therapist, and a gay man. All of these parts of my life are integral to each other. None is dependent and none are more important, they simply are. All human beings have different aspects to their existence and persona. It is how we understand each part, and the relationship of the parts to the whole, that makes our effectiveness as a therapist balanced and true. (Lee, 2008)

This statement best encapsulates my feelings about being queer and a music therapist.

In the spirit of queer autoethnography's emphasis on 'becoming' through creative acts, my paper's reviewer suggested the possibility of an interactive, dialogic space where the reader/listener might be able to engage in their own creative processes (e.g., art, music, dance, poetry, imagining, etc.) in response to my current work, taking up the questions of what you hear/read, how it relates to what I've explored, how it impacts/relates to your own identity, how it might queer music therapy in some way, and so on. With this suggestion, the editors of this special issue have created such a space, which can be found at https://padlet.com/queeringMT/interactive. Instructions for how to make use of the Padlet will be found within the interactive space by clicking on the "How to Post on Padlet" post. You are encouraged to utilize this space to share your own creative responses and for us to further interact with and explore the ideas reflected in this paper and in my music and poetry.

\section{Music and Poetry}

Throughout my career as professor of music therapy at Wilfrid Laurier University (1998-2019), I have given concerts of improvised music. These concerts have focussed on the aesthetic-emotional content of my experiences as a music therapist. My contribution to this queering music therapy special issue is essentially musical. On October $9^{\text {th }}$ and $12^{\text {th }} 2018$, I recorded 12 hours of music in four separate sessions (Refer to 
figure: Recording Session, Maureen Forrester Hall). These sessions comprised of semicomposed and composed pieces, as well as free improvisations. The focus of the music was to reflect on my work as a queer therapist - a personal exploration through an artistic, non-verbal perspective. The five pieces included in this article came from the final recording session. During this time, I improvised without pre-conceived musical ideas. I considered my experiences with clients both individually and collectively. These recordings were genuine expressions that sounded my authentic self. Not only clear representations of my sexuality and passion for music, but also expressions that articulated other intersecting aspects of my identity - my gender, race, ability, vulnerabilities and privileges in life. Music by its sheer force can speak to that which is human in everyone.

The improvisations are for the most part tonal, slow, legato, and post-minimalist in style. I purposefully did not improvise pianistic flourishes. Instead, I played the piano as if it were a string orchestra. This final three-hour recording session became one continuous movement with measured emotional silences in between. I remember an awareness of stepping back and watching myself play. This was an experience that often happened in my work in end-of-life care when I improvised with clients who were critically ill or dying. By creating space and minimal musical structures, it was always my intention that the listener would be able to enter into the music and hear themselves, as well as create their own impressions and experiences of being human. This final recording session was emotionally intense. In order to experience the full resonance of the piano, I suggest listening to the recordings through either a separate audio system or on headphones. The improvisations are not meant to be perfect performances, and minor slips were left unedited as a reflection of the creative process. Each musical contemplation is placed in context through poetry.

\section{My Queering Musical Soul}

I was afraid

A wave of vulnerability swept over me

It came slowly at first,

Then enveloped my whole being

I felt desperately unprepared.

HIV/AIDS had stormed into my life

Before I had time to catch my breath

How could I merge my identities?

As a music therapist?

And a gay man?

There were no texts

Supervisors to help guide me

I knew I had to trust the moment

But how?

From these feelings of uncertainty

Our music soared

I could not have anticipated

The emotional canyons that would open as sessions began.

Everything I thought I knew

Became irrelevant

Everything that was tangible

Seemed to disappear into the mist

I lived in the musical unknown.

I improvised with clients

Endless music

Endless playing. 
I improvised for myself

To reflect

The intimacy of our developing musical relationships.

Through acknowledging my insecurities

I found a path

Of authenticity.

Music stretches out in front of me...

intervals,

harmonies,

melodies open,

embracing sounds,

resonance,

warmth and clarity,

thematic ideas,

freedom of form,

expressing,

searching.

A cello-like melody rises

Music becomes resilient

Potency of living

Strength needed

To embrace

My queering musical soul.

Contemplation 1 (6:07)

Audio: https://soundcloud.com/voices-mt/voices-1-v1

\section{Amidst the Dying There was Living}

The isolation of tones

Being alone

Not knowing

Music

It is sad...

so sad.

Sadness I have been holding...

for so long.

Stillness and movement...

sorrow,

melancholy,

inevitability.

Why did this happen?

So many young people

So many deaths

Musical compassion

United.

Every note has its place

Each note represents a life

Within the coldness...

there was harmony and light.

From loss came strength

In music, we were whole.

Contemplation 2 (9:57) 
Audio: https://soundcloud.com/voices-mt/voices-2-v1

\section{Transcendence}

Peace

Quiet

Stillness

Tranquility

Stability

Hymn

Melody with no end.

I have grieved

So many clients

So much beautiful music

Invocation of life

Acceptance of death

I rest.

Contemplation 3 (3:56)

Audio: https://soundcloud.com/voices-mt/voices-3-v2

\section{Dance}

I need to dance, he said...

I need you to play my dance

I need to explore my living and dying

My prayer of being queer and dying of AIDS.

He crouched in a small ball in the centre of the room

I took my seat at the piano.

The quiet of the room engulfed me and so...

his creation began.

Small movements at first

I mirrored with open rubato phrases

His movements

My music

Becoming connected

His dance became a ballet

An invocation of life.

I was humbled...

freedom,

flying,

soaring,

surgency of expression,

so much pain,

uncertainty.

Life is fleeting

In that moment...

the only certainty was dance.

He left in silence

His only gesture

A simple nod

And he was gone.

I never saw him again. 
Contemplation 4 (4:19)

Audio: https://soundcloud.com/voices-mt/voices-4-v1

\section{Waiting}

I sat at the bedside...

waiting.

The silence between us

Stretching forward

Moistening his lips...

waiting.

Reaching out to the membrane

Between life and death...

waiting.

Music had been his life

We shared

So much

In music.

What of this moment?

How many moments before

And now

An affirmation of serenity...

waiting.

There was peace

A life treasured

Shared in music.

I stepped away to live

To remember

Our testament.

Music is passion

Music is meeting

Music is life

Music is queer

I remember...

waiting.

Contemplation 5 (5:13)

Audio: https://soundcloud.com/voices-mt/voices-5-v2

\section{Coda}

Throughout my career as a music therapist, I have danced between theory and practice, art and science. I have struggled with the need to provide clinical outcomes and theory and my belief in the artistic beauty of music to affect therapeutic change. In being guided to queer autoethnography by the guest editors of this special issue, I found an authentic space in which to explore the artistic integrity of my clinical practice. Further, using queer theory as a theoretical frame, I was, at first, unsure if I could adequately contextualize through words the emotional potency of the music I had improvised. I continue to reflect on my power and privilege as a white man and my struggles in trying to find my place in the world as queer. The improvisations and poetry shared in this piece are direct representations not only of my emotional responses to the clients I have worked with, but also my role as a gay cisgender man in a primarily heterosexual cisgendered profession. Understanding my role as a queer music therapist has been complex. I have challenged my need to be open and honest in my writings 
and how this has affected my contribution to the music therapy literature. When I first began creating words for this article, I struggled with how I would be able to share the deep sense of yearning I had expressed through the improvisations. Trying to contextualize and share my written experiences as a queer music therapist through sentences at first seemed futile. On further reflection, I began to realize that I would need to explore through the ambiguity of poetry if I was to authentically share my experiences working with clients as a queer music therapist. Queer autoethnography has provided a space to use poetry and music as a means of exploring my professional and personal identity, and I hope it will, in some way, encourage the same for others.

\section{Acknowledgements}

I would like to thank all the clients I have had the privilege to work with throughout my career as a music therapist. To Paul Nordoff, who I never met, but who has been my constant musical guide as a clinical improviser. Thank you, Pete Lamont for the recording sessions and subsequent editing and Graylen Howard for your professionalism and support. Thank you Candice and Maevon for opening the doors to queer autoethnography and your theoretical support and guidance. And to my husband Rainier, who has always loved me and championed my work.

\section{About the author}

Colin Andrew Lee is Professor of Music Therapy at Wilfrid Laurier University, Waterloo. Following piano studies at the Nordwestdeutsche Musikakademie, he earned his Postgraduate Diploma in Music Therapy from the Nordoff-Robbins Music Therapy Centre, London, and his Ph.D. from City University, London, culminating in the music-centred theory of Aesthetic Music Therapy (AeMT) that was the subject of Colin's debut monograph The Architecture of Aesthetic Music Therapy (Barcelona Publishers, 2003). His subsequent books include, among others, Improvising in Styles: A Workbook for Music Therapists (with Marc Houde; Barcelona Publishers, 2011), Paul Nordoff: Composer and Music Therapist (Barcelona Publishers, 2014), and Music at the Edge: The Music Therapy Experiences of a Musician with AIDS (2nd edn; Routledge, 2016). In 1996 Colin helped form the Towersey Foundation, a charity that promotes and creates positions for music therapy in palliative and end-of-life care.

\section{References}

Adams, T. E., \& Holman Jones, S. (2008). Autoethnography is Queer. In N. K. Denzin, Y. S. Lincoln, \& L. T. Smith (Eds.), Handbook of critical and indigenous methodologies (pp. 373-390). Thousand Oaks, CA: Sage.

Adams, T. E., \& Holman Jones, S. (2011). Telling stories: Reflexivity, Queer Theory, and Autoethnography. Cultural Studies <.> Critical Methodologies, 11(2), 108-116.

Bain, C., Grzanka, P., \& Crowe, B. (2016). Toward a Queer Music Therapy: The Implications of Queer Theory for Radically Inclusive Music Therapy. The Arts in Psychotherapy, 50, 22-33.

Boggan, C., Grzanka, P., \& Bain, C. (2018). Perspectives on Queer Music Therapy: A Qualitative Analysis of Music Therapists' Reactions to Radically Inclusive Practice. Journal of Music Therapy, 54(4), 375-404.

Gumble, M. (2019). Embodied Speech Through Song: A Queer Autoethnographic Exploration of Gender Affirming Voicework in Music Therapy (Master's thesis). Slippery Rock, PA: Slippery Rock University.

Holman Jones, S., \& Harris, A. (2019). Queering Autoethnography. London, GBR: Routledge.

Lee, C. A. (2003). The Architecture of Aesthetic Music Therapy. Gilsum, NH: Barcelona.

Lee, C. A. (2008). Reflections on Being a Music Therapist and a Gay Man. Voices: A World Forum for Music Therapy, 8(3), https://doi.org/10.15845/voices.v8i3.415.

Lee, C. A. (2016a). Music at the Edge: The Music Therapy Experiences of a Musician with AIDS. London, GBR: Routledge. 
Lee, C. A. (2016b). Aesthetic Music Therapy. In J. Edwards (Ed.), The Oxford Handbook of Music Therapy. Oxford, UK: Oxford University Press.

Lee, C.A. (2019, in press). Musical Awakenings: The Experiences of a Queer music Therapist in the Face of HIV and AIDS. In F. Everett Maus \& S. Whiteley (Eds). The Oxford Handbook of Music and Queerness. Oxford, UK: Oxford University Press. 